\title{
NORMATIZAÇÃO PARA USO DO ÓXIDO NITROSO NA CLÍNICA ODONTOLÓGICA
}

Grasielle KARPSTEIN, Wilson Kenji SHIROMA

Apesar do oxido nitroso ser usado há mais de cem anos no mundo inteiro, seu uso no Brasil ainda é restrito a poucos profissionais, a falta de informação causa receio por parte do profissional e também por parte dos pacientes, pois pela pouca divulgação ainda existem muitos mitos envolvendo essa técnica. Apenas há três anos o Conselho Federal de Odontologia baixou uma resolução estabelecendo normas para habilitação do Cirurgião Dentista na utilização de oxido nitroso em consultório na sedação consciente. Antes disso muitos cirurgiões dentistas se beneficiavam de lacunas na Legislação, utilizando-o, não raras vezes, de forma indiscriminada. O presente trabalho tem por objetivo trazer ao conhecimento dos acadêmicos e profissionais de odontologia as novas legislações para utilização do oxido nitroso, promovendo a discussão através de comparação da Resolução do CFO de 2004 e das normas que a secretaria de Saúde do Estado de São Paulo implementou em 2005. 